\title{
A transcultural experiment ${ }^{\dagger}$
}

\author{
Lucian Chișu* \\ "G. Călinescu" Institute of Literary History and Theory, Calea 13 Septembrie 13, 050711 Bucharest, Romania \\ National Museum of Romanian Literature, Piața Presei Libere 1, Corp A4, Etaj 2, 013701 Bucharest, Romania
}

\section{Article info}

History:

Received June 21, 2016

Accepted July 15, 2016

Published August 1, 2016

Key words:

literature

identity

mentality

multiculturalism

\begin{abstract}
The project of creating a graphic and cartoons archive (portraits of the great Romanian writers from various literary eras), accomplished with the support of dedicated artists around the world, has gained a new historical-literary dimension, as a result of the huge interest it has stirred up. After a certain geographical and qualitative selection, two editions have been published on paper: one in Romanian and one in English, each of them comprising 3600 images by artists from all continents (112 countries). This unprecedented book, called $A$ History of the Romanian Literature drawn by the Great Illustrators of the World (Romanian Literature Museum Press, 2011) presents transcultural aspects that are well worthy of attention from literature historians, biographers, word and image artists (writers, graphic designers, cartoonists), but also from cultural studies specialists (anthropology, semiotics, mentalities), due to the unusual form of open dialogue.
\end{abstract}

1. We all live with this incontestable reality that is globalisation. The effects of this phenomenon in areas like economy, social and culture have generated numerous disputes among the specialists interested of the contemporary society's challenges and the "clash of civilizations". Due to the gravitational force that knowledge exercises over billions of people, human civilization continuously reconfigures itself in a Brownian move, through Informational Knowledge Society $(\mathrm{IKS})^{1}$, on a world level ${ }^{2}$.

Between the cultural phenomenon and the expectations of the society ${ }^{3}$, the changes generated by the new technologies have literally shaken the relations, creating a huge gap, manifested in the predominance of the effects of globalisation over the structures of tradition. The consequence of this pressure exercised through the economic vector led to a continuous erosion of the identitary aspects, expressed in national linguistic codes and preserved through ethical and moral sets, that are characteristic for those specific nations. If each of the cultural languages has kept its grammar structure, one couldn't say the same about their lexic, whose nucleus (essential vocabulary) was invaded, in the Informational Knowledge Society, by unique terms describing technologies and instruments of communication, that are available to billions of users. The observation of a famous French linguist (A. Meillet) - namely that the history of civilisation ${ }^{4}$ is reflected into the etymology of words-proves its premonitial character for this "terminal" phase, when the powerful destructuring tendency of old values and identitary tradition takes place after forming an authentic communicational mainstream. Due to globalisation effects, the term national has been placed

\footnotetext{
${ }^{\dagger}$ A version of this text appeared in "Caiete critice", issue 6 (296), 2012, p. 39-49.

*Email address: lucianchisu@gmail.com.

${ }^{1}$ The society in which the information is acknowledged as main (re)source, and the information production and consumption is the most important type of activity.

${ }^{2}$ It should be reminded that the top of the most common professions is taken by ones that are very new, and were not even existing five years before.

${ }^{3}$ Simmel (1987) argued that the crysis in culture is "the result of conflict among the processes of life, which doesn't know any rest, and its forms of cultural expression, which do not know what change is".

4"La langue étant de tous les faites humaines le plus manifestent social—car ni langue n'est imaginable sans la société, ni la société des hommes sans langue-les conditions sociales dominent le langage”, in "Bulletin de la Sociétée Lingvistique de Paris, XXV", fasc. 2. p. 2, apud Graur \& Wald (1977).
} 
Lucian Chișu

into the area of meanings of a different concept, identitary, partially synonymous, which allowed crossing the axiological rigors that act according to tradition. Even tradition itself has been annexed components with a consumerist role. The study of the new social-cultural forms (Baber, 2012), marked with prefixes such as inter-, multi-, trans-, or with nouns like cosmopolitanism and hybrid, which form themselves linguistic compositions along the terms culture / cultural, has determined a conceptual relaxation and new interdisciplinary approaches. This sort of studies and research open new horizons, that naturally go cross subjects, aiming multiple surprising contexts, yet filled with valuable information ${ }^{5}$.

2. Agreeing to the previously said, the present article refers to the chances offered to cultures that are spread on small geographic areas (in our case, Romanian literature), of making themselves known (visible) in the contemporary multicultural dialogue. From the beginning, we mark the Romanian language's disadvantage of being active only on a small linguistic area, as compared to the widely and internationally spread idioms, such as English, French, Spanish, Chinese. This is why we have taken on an experiment in which the "independent" laws of multiculturalism have been conjuncturally reconfigured.

Out of the two terms (multi- and / or trasculturalism), from the title of the Conference, we prefer the transculturalism (Cuccioletta, 2001-2002) ${ }^{6}$, like it was manifested within the experiment. The situation represents an aspect that is different from the standard intercultural communication research ${ }^{7}$. The aim is to optimise, not find dysfunctions; under this aspect, the term transculturalism could easily be replaced by the hybrid culture syntagm, as per Ryszard Kluszczynski ${ }^{8}$, that we only partially agree with.

The experiment has resulted in creating an anthology (Ioniță, 2009) and comprised addressing the graphic designers' "community" all over the world with the matter of expressing, according to their profession, a synthetical and cultural point of view over the most important Romanian writers of all times. They (the respondents) were required to adapt to the new inter- and multicultural context, under the following attributes: (a) an invitation to dialogue through a (foreign) unknown subject; (b) gathering information and, later on; (c) accomplishing, due to the gains of knowledge / information, the transcultural dialogue, with (d) its varied forms of interpretation. Relativising "one's own cultural field" (Bourdieu, 1993, p. 41), which meant interrogating and negotiating a common ground of knowledge, as well as the newly achieved capacity, was also taken into consideration. A first conclusion refers to gathering information and then ordering it into what was called a panorama of Romanian literature (rather imprecise, but persuasive name). The edification was possible on both valoric and historical-literary (diachronic) criteria. The explanation for realising this type of good practice is due to the cast's ability to quickly and efficiently "filter" the information. In order to gain recognition in the profession they chose, these graphic designers, regardless of nationality and location, share common real qualities, such as intelligence, curiosity, fantasy, power of abstracting, speed, and each of these is served by their own artistic talent.

\footnotetext{
${ }^{5}$ Their diversity can be noticed everywhere. For instance, the Doctor's thesis called Food as a Transcultural Metaphor (Food Imagery and Ethnocultural Identities in Contemporary Multicultural Women Writing in Canada) by Katarina Hinnerova from the Faculty of Art. Departament of English and Amercian Studies, Masaryk University, Brno (2007).

${ }^{6}$ Transculturalism is defined as "seeing oneself in the other".

${ }^{7}$ This kind of research and studies is, on its vast majority, dedicated to studying the (concrete) state of facts and do not target ... challenging them, as it happens in this case. On the other hand, we are not particularly happy to note that, for instance, many of the revealing discoveries within the communication have resulted into studies oriented towards people with expression / communication disabilities.

8 "One of the most important factors of the hybrid condition of contemporary arts is the complex relationship between arts and sciences and technologies. Such relations develop a new concept of third culture, not based-as in the theory of John Brockman-on the conflict between traditional humanistic values and scientific systems, but on the interactions between them. (...). Hybrid cultures are phenomena of essential connections in the present. They emerge from diverse and complex influences. Hybrid cultures are mergers that combine past and present, local and translocal, space and place and technoscape. Hybridity is expressed in various cultural contexts and in the in between spaces of arts, media, science and technology. Under the sign of the digital and the global, hybridity connotes a cultural manifestation of multiple appearances, as in cyberspace and multiple selves" (ISEA 2011 Istanbul. The $17^{\text {th }}$ International Symposium on Electronic Art. 14-21 ${ }^{\text {st }}$ of Sept. 2011).
} 
3. The other interpretative situations flow from the answers received, and presented as a volume of 450 pages and approximately 3500 images. From the drawn conclusions, we mark:

$A$. The collaborators of this transcultural experiment represent 122 nations, given in alphabetical order and spread throughout the world, allowing us to note its mondialising, multi- and transcultural aspect. One should note that, without the communication technologies, this purpose would not have been touched, at least not in its spreading area and the simultaneity effect of the communication. The present summary grants globalisation a new statute: that of being axiomatic.

B. "The chapters" of this History... come in varied sizes, according to the importance (value) of the targeted personality. It is easily noticed that the internal sample (the notoriousness of the writers in the national cultural context) keeps the same proportions as the world spread vision. The explanation is found in the good organisation of valoric structures present in the direct access documentary sources. The most substantial are focused on I.L. Caragiale [642 icons], Mihai Eminescu [342 icons], Mircea Eliade [124 icons], Eugen Ionescu [112 icons], Nichita Stănescu [112 icons], Nicolae Iorga [102 icons], Emil Cioran [90 icons] and Tristan Tzara [70 icons]. If, in this context, the first two, (and also Nichita Stănescu) are the most cherished authors in the Romanian area, the authoritarian presence of the others is decisively due to their international presence. This way of representation certifies, through external data, the internal historical and literary evaluations. Within the national / international report, they rank higher than Mihail Sadoveanu [39 icons], Tudor Arghezi [15 icons], Liviu Rebreanu [15 icons], Marin Preda [15 icons], writers whose essential contribution to the development of national literary art remains "captive" in our linguistic code, as one could say.

C. Because there are a few thousand "portraits" in the History, and because this year we mark 100 years since I.L. Caragiale's death, as a mark of our appreciation, we have resorted to the illustrations made for him. In order to keep this overwhelming majority from narrowing down the generalising character of the "message", some other few exemplifications have been used. As shown above, the information offered by the respondents have, in themselves, a complexity that is easily subject to interpretation. These can be drawn into types of information:

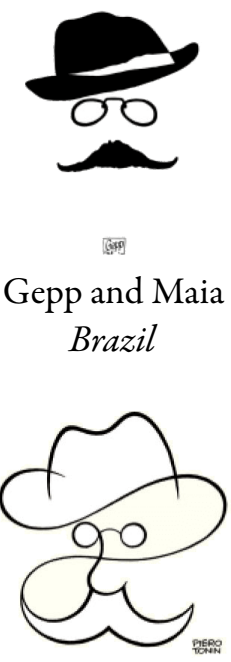

Piero Tonin Italy

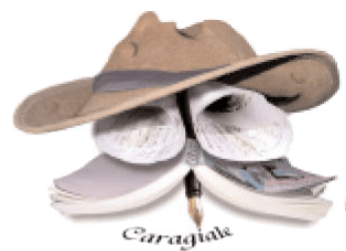

Fil Foutisse

France

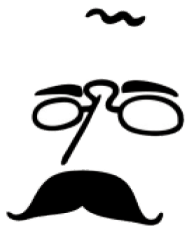

Quel

Spain

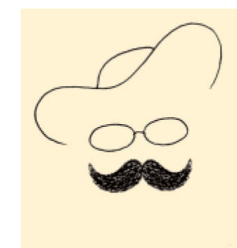

Reiner Schwalme

Germany

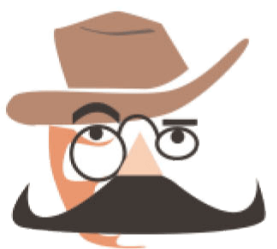

Mosquera Beceiro Spain

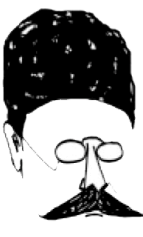

-

Gokul T G India

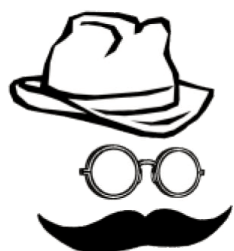

T. Sittipongsutti Thailand

Figure 1

a) Some of the images are the result of a remarkable intuitive and summarising ability, an aspect under which I.L. Caragiale is reconstructed from only a few details $/$ lines ${ }^{9}$, proving semiotic valences (Figure 1).

\footnotetext{
${ }^{9}$ In order to represent the human face, the photo camera "constructs it" with many contrasting dots (pixels). The video
} 


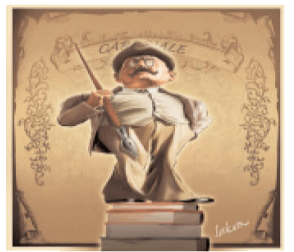

Thiago Lobo Brazil

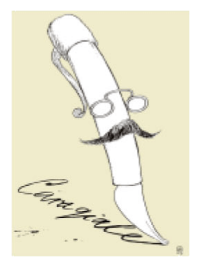

V. Sardinha Portugal

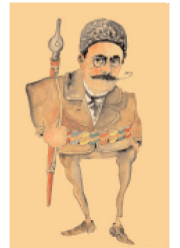

Tsocho Peev

Bulgaria

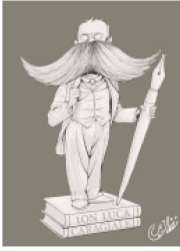

Nedal Deep

Syria

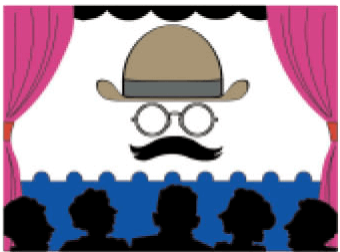

Roberto Alarcon

Guatemala

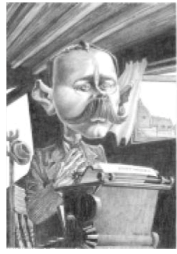

D. Gray

United Kingdom

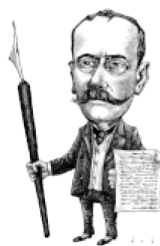

Doddy Iswahyudi Indonesia

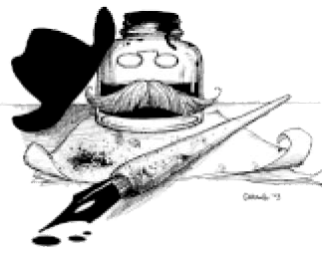

S. Carroll

United Kingdom

Figure 2

b) Iconography is more present than the other types of information, fact that can be explained by the profession of the authors, whose means of approach, lacking literary text-from case to case, the access was different-resumed to a photography or cartooning a portrait. Beyond the image resulted, the cultural data is added through series of symbols of the tools of writing (writing feather, book, nib pen, typewriter, manuscript, library; see Figure 2) - ephigies of their belonging to the guild; On the other hand, the images cumulate information about the writer's biography, his work, characters or the activity of managing magazines.

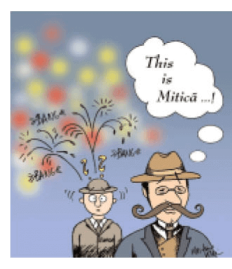

Martina Klein

Germany

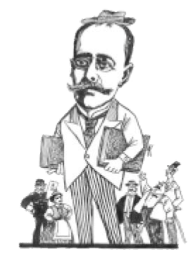

Nikolaj Kapusta

Ukraine

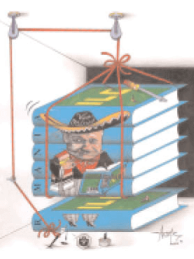

Arturo Rosas

Mexico

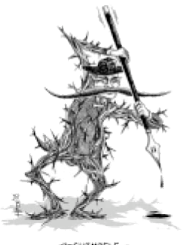

Matt Duck

United Kingdom

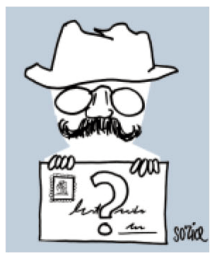

Guillermo Soria

Spain

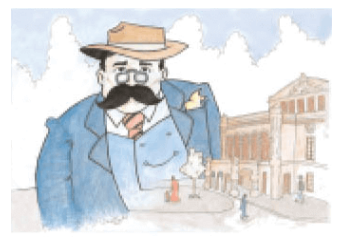

David Baillie

United Kingdom

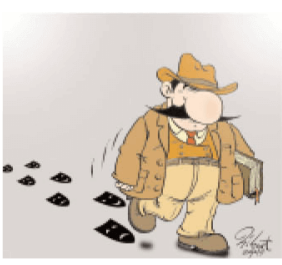

Hikmet Cerrah Turkey

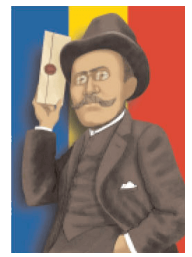

Diane Barton

United States

Figure 3

c) Many of the drawings, graphical presences or cartoons show a historical-literary information, sometimes very detailed, fact which proves that the dialogue has suscitated more vast investigation, subtly interpreted

camera can produce the same human figure by using approximately 900 horizontal lines, whose fragmentation generates the image. Or, it is known that portraitists can get the same performance by drawing one single continuous line, through which both the image in itself, as well as temper features, can be presented. 
and represented (Figure 4). For instance, the friendship between Eminescu and Caragiale is often represented by picturing the two next to Veronica Micle (last panel of Figure 4), the female poet which was involved with both of them.

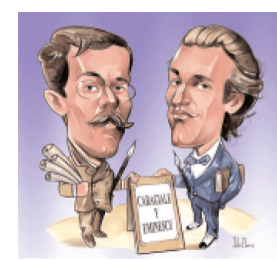

Julio Ibarra

Argentina

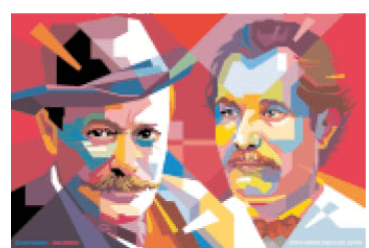

S. Priyanto

Indonesia

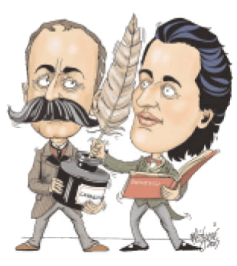

Serge Métivier Canada

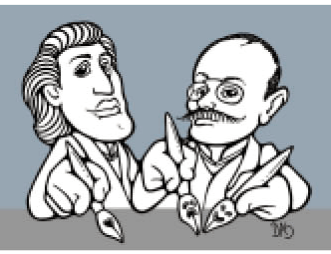

Daniel Sahade Japan

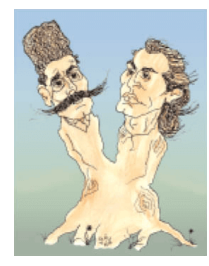

Imre Gaspar

Hungary

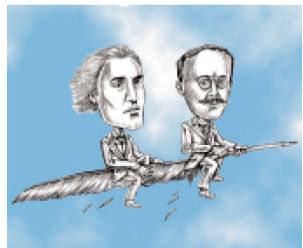

K.A. Ligones Arabia

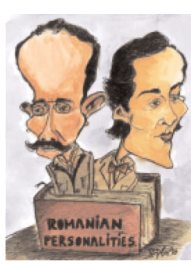

Kumar Bora India

Figure 4

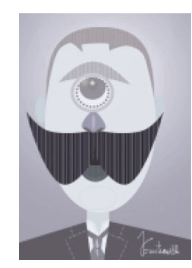

S. Martinez Argentina

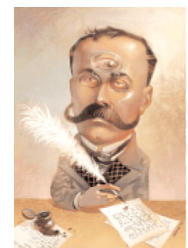

Svetlin Velinov Bulgaria

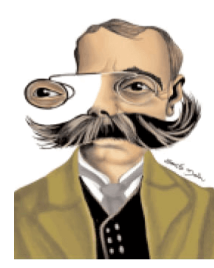

Souto Maior Brazil

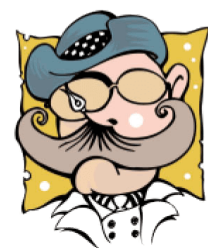

J. Briceno-Rac Panama

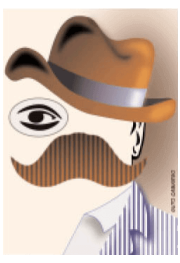

Guto Camargo Brazil

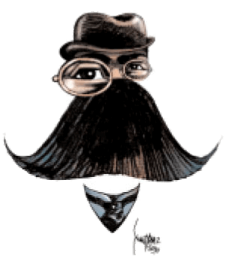

Sevket Yalaz Turkey

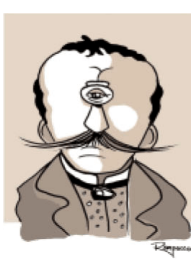

Marcelo Rampazzo

Brazil

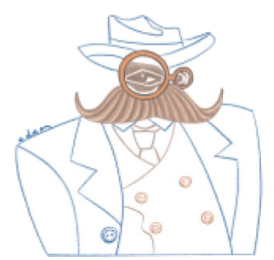

Eden

Uruguay

Figure 5

d) Among the means of representing quotes from the work of the writers presented in the History..., one can also find inventive solutions. For instance, what we could call "the Cyclops eye" attached to I. L. Caragiale refers to his well-known formula "I have a huge feel and a monstrous sight" (Figure 5).

It is also through differentiation that the national component can be drawn (Figure 6), but also the references about its universal value (Figure 7).

4. Regarding the transcultural character of these images, they draw attention to portraits of the most notorious Romanian writers (Figure 8). 


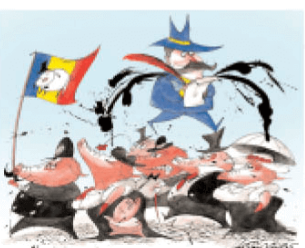

Gaston Vinas

Argentina

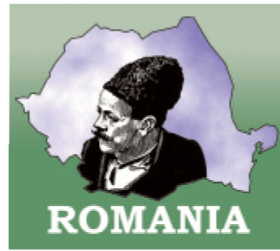

Arafeh Kahil

Jordan

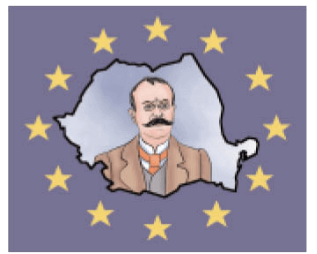

H. Al-Gayeb

Babrain

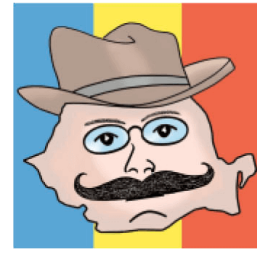

F. Rasoamaharo Madagascar

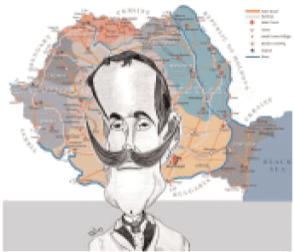

Marcelo Jorge

Brazil

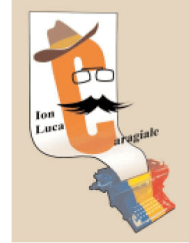

Kalifa

Trinidad Tobago

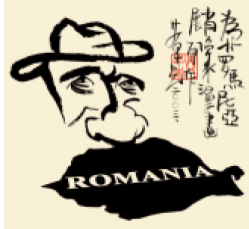

Ai Zaoxian

China

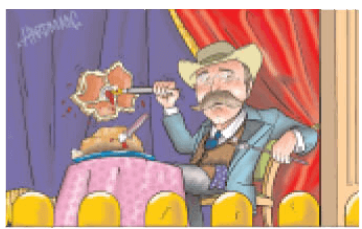

Kalifa

Trinidad Tobago

Figure 6

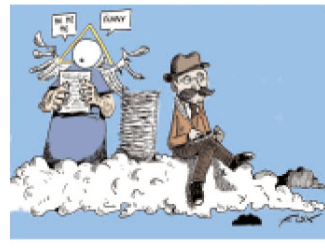

Fox

France

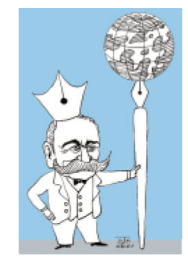

Kim Sungjoo

Korea

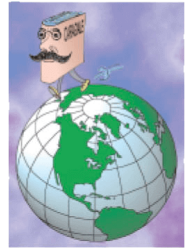

Yolette Mengual

Haiti

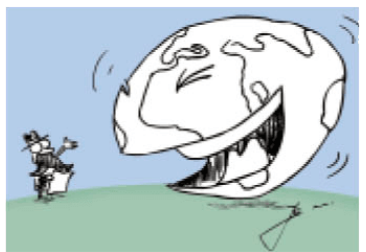

Zemgus Zaharans

Lithuania

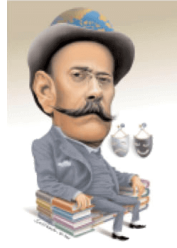

Susthanto

Indonesia

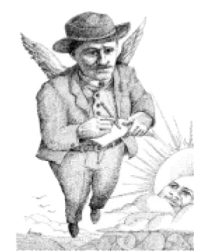

M. Imrane Coulibaly Mali

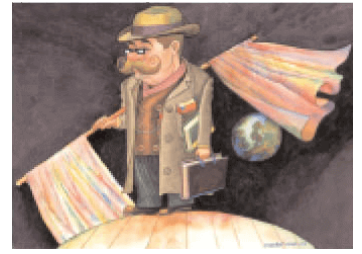

Ali Mandalawi Iraq

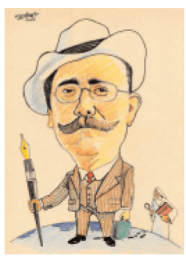

Shujaat Ali

Pakistan

Figure 7

Without listing the numerous examples that we can appeal to, we only invoke two fully clarifying examples. Regarding Caragiale, the force of transposing into a different cultural horizon is clearly manifested in the representation made by a Japanese graphic designer, who adapts the ironic incisiveness of I. L. Caragiale's drama, picturing him as a fighter (samurai), with a pen instead of sword and many other details in sight.

The same artist handles Eugen Ionescu, resorting to the well-known Asian shadow theatre, in order to assimilate him. A... rhino is profiled ("game" of shadows made with hands) on the same wall where the theatre writer is found (innuendo for the theatre play The Rhinos). For an African author, the transcultural assimilation of I.L. Caragiale and Eugen Ionescu is shown by applying African facial characteristics to the first writer, and tribal totem tattoos on the face of the second one, thus suggesting that he is accepted as one of them. The same happens with Mihai Eminescu and Emil Cioran, in the view of Egyptian and Turkish designers, who anthropologically "see" the two writers as people of their own. 


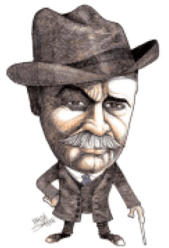

N. Sooben

South Africa

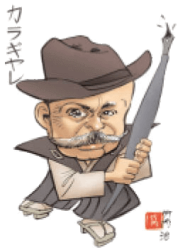

Edson O. Takeuti Japan

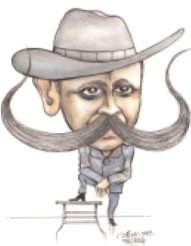

N. Mpangala

Tanzania

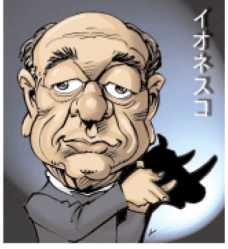

Edson O. Takeuti Japan

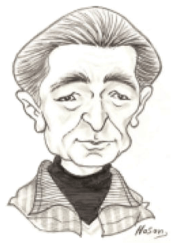

Hasan Said

Egypt

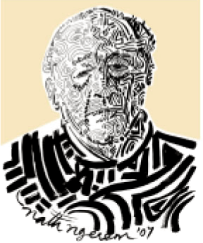

Nath Ngerem Nigeria

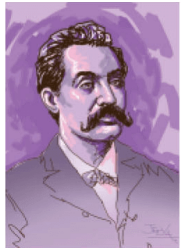

V. Jeevananthan India

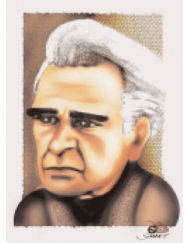

Demir Yalcin Turkey

Figure 8

5. The tendency shown by most of the volume's authors is to represent the best known and genius Romanian writers through post-modernist message visions, which we consider to be another transcultural effect. We see these representations different from a simple fashion, but a way of dialogue with the contemporary world, a dialogue that is mostly accessible to the works we can truthfully call immortal. It is the only way we can explain the enormous catch that I.L. Caragiale is enjoying, and whose death took place more than one century ago: his work's message has kept an intact actuality, making it possible to metabolise it in any surprising postmodernist variants (Figure 9).

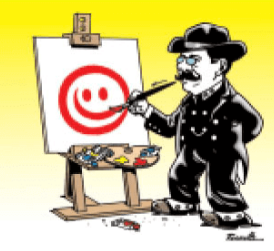

F. A. Ferreira Brazil

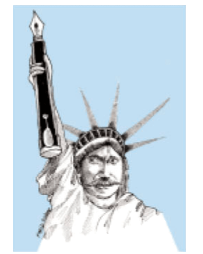

Farid Oidder Morocco

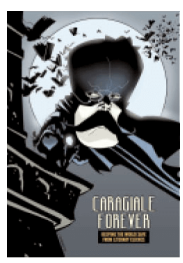

V. Kalvachev Bulgaria

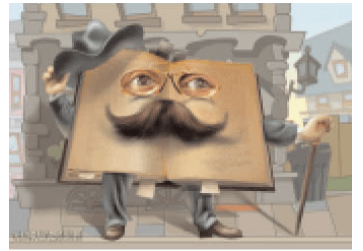

Michail Neiman

Russia

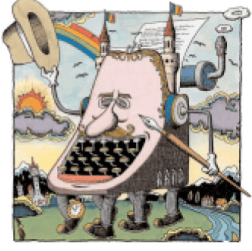

Ken Crane Japan

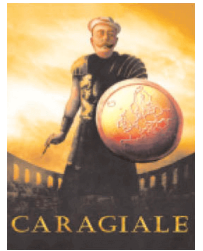

Deano Car

United States

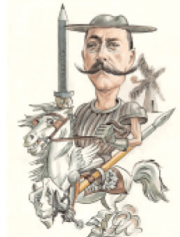

M. Amanbaev Kazakhstan

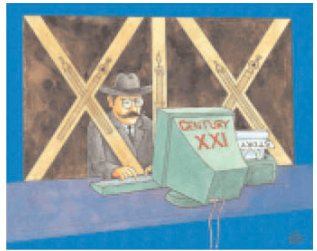

M. Eshonkulov

Uzbekistan

Figure 9

6. As a whole, $O$ istorie literaturii române in viziunea marilor graficieni ai lumii [History of the Romanian Literature drawn by the Great Illustrators of the World] represents a notable transcultural effort and presents some of its most important attributes:

1. The great writers can be good ambassadors of the culture they represent, if there is an appeal made to 
new, still unexplored ways of dialogue. Through these, their creation can substantially contribute to awareness among cultures.

2. The contemporary means of promotion have surprising resources and will certainly influence the society, as they are completely unpredictable. Only due to the new communication technologies and amazing upgrading speed, it was all possible. They facilitate fast, almost instantaneous reactions.

3. The assimilation of the cultural contributions of writers and their penetration into IKS dialogue, regardless of their era and language, is now comprised into the "grids" of postmodernism. The works that continue to exist through the interrogations and answers of the new generations will be privileged.

As a result, the experiment would have been doomed to fail, had it not it been for the beneficial effects of mondialisation (globalisation), that not all of us are equally optimistic about.

\section{References}

Arasse, D. (1996). Le détail. Pour une histoire rapprochée de la peinture, Flammarion, coll. Champs arts, Paris.

Arnheim. R. (1976). La pensée visuelle, Flammarion, Paris.

Baber, H.E. (2012). Dilemmas of Multiculturalism: An Introduction, in “The Monist”, vol. 95, iss. 1, Jan., p. 3-16, Crossref.

Bourdieu, P. (1993). The Field of Cultural Production, Columbia University Press, New York.

Brooks, R.L. (2012). Cultural Diversity: It's all about the mainstream, in “The Monist”, vol. 95, iss. 1, Jan., p. 17-32, Crossref. Condon, J. C. \& Yousef, F.S. (1975). Introduction to intercultural communication, Bobbs-Merrill Company, New York.

Cuccioletta, D. (2001-2002). Multiculturalism or Transculturalism: Towards a Cosmopolitan Citizenship, in "London Journal of Canadian Studies", vol. 17, Plattsburgh State University of New York, Interdisciplinary Research Group on the Americas, Jan. 15.

Drăgănescu, M. (2001). Societatea informațională a cunoașterii. Vectorii societății cunoașterii, în Filip, F. Gh. (ed.), Societatea informațională. Societatea cunoaşterii (concepte, soluții şi strategii pentru România), Academia Română, Bucureşti, p. 43113.

Durand, G. (1992). Les structures anthropologiques de l'imaginaire, Dunod, Paris.

Huntington, S. (1998). The Clash of Civilisations and the Reamking of World Order, Antet, Bucureşti.

Graur A. \& Wald, L. (1977). Scurtă istorie a lingvisticii, Editura Didactică şi Pedagogică, Bucureşti.

Ioniță, N. (2009). O istorie a literaturii române desenată de marii graficieni ai lumii, Editura Muzeul Literaturii Române, Bucuresti.

Ioniță, N. (2012). I. L. Caragiale - un omagiu planetar, 3 volumes, 1500 pages, Editura Muzeul Literaturii Române Bucureşti.

Lewis, J. (2002). The Cultural Dynamic, „From Culturalism to Transculturalism”, Iowa Journal of Cultural Studies 1 (Spring 2002).

Mitchell, W.J.T. (2009). Iconologie. Image, texte, idéologie, Introduction, Avant-propos des traducteurs, Les Prairies ordinaires, Paris.

Pauzet, A. (2005). Représentations picturales et imaginaire collectif, in "Etudes de Linguistique Appliquée. Revue de didactologie des langues-cultures", vol. 2, iss. 138, p. 137-151.

Slimbach, R. (2005). The Transcultural Journey, in “The Interdisciplinary Journal of Study Abroad”, vol. 11, p. $205-230$.

Toynbee, A.J. (1997). Study over history, Humanitas, Bucureşti.

Simmel, G. (1987). Der Konflikt der modernen Kultur, în Das individuelle Gesetz: Philosophische Exkurse, herausgegeben und eingeleitet von Michael Landmann, Frankfurt a. M., Suhrkamp, p. 148-173.

Vianu, T. (1982). Studii de filozofia culturii, Editura Mihail Eminescu, Bucharest. 